TITLE:

\title{
The Medusa of Thecocodium quadratum (Werner) (Anthomedusae, Ptilocodiidae) from Southern Japan
}

$\operatorname{AUTHOR}(S)$ :

Kubota, Shin

\section{CITATION:}

Kubota, Shin. The Medusa of Thecocodium quadratum (Werner) (Anthomedusae,

Ptilocodiidae) from Southern Japan. PUBLICATIONS OF THE SETO MARINE BIOLOGICAL LABORATORY 1993, 36(1-2): 89-92

ISSUE DATE:

1993-03-30

URL:

http://hdl.handle.net/2433/176219

RIGHT: 


\title{
The Medusa of Thecocodium quadratum (Werner) (Anthomedusae, Ptilocodiidae) from Southern Japan
}

\author{
Shin Kubota \\ Seto Marine Biological Laboratory, Kyoto University, \\ Shirahama, Wakayama 649-22, Japan
}

With Text-figure 1

\begin{abstract}
The medusa of Thecocodium quadratum (Werner) is described and illustrated based on a specimen collected at Kuchinoerabu Island, Kagoshima Prefecture, southern Japan. This is the second collection of this species and the first record of the medusa from the sea. The present medusa is different from the holotype in having a greater number of linear spurs of nematocysts at the umbrellar margin and more distally extended, oval clusters of nematocysts on the exumbrella.
\end{abstract}

Key words: Thecocodium quadratum, medusa, spurs of nematocysts, oval clusters of nematocysts

\section{Introduction}

In the hydroid family Ptilocodiidae seven nominal species in four genera have been described (Coward, 1909; Stechow, 1909, 1913, 1926; Leloup, 1940; Bouillon, 1967, 1978; Brinckmann-Voss, 1970; Edwards \& Harvey, 1983; Jarms, 1987; Hirohito, H. M. the Showa Emperor, 1988). Among them Thecocodium quadratum (Werner) is one of the two species that releases immature medusae, differing from the others that produce eumedusoid to styloid. Jarms (1987) obtained the mature medusa of $T$. quadratum after laboratory rearing of the hydroid which was collected only once from the type locality by Werner (1965). The morphology of this medusa is unique among hydromedusae, particularly in having exumbrellar furrows at the perradii. As a new member of the Japanese hydrozoan fauna, a well-developed medusa of $T$. quadratum has been collected from the sea. This specimen is here described and illustrated, pointing out morphological differences between the present medusa and the type material.

\section{Thecocodium quadratum (Werner, 1965)}

(Fig. 1)

Ptilocodium quadratum Werner, 1965, pp. 11-12, Figs. 4, 5;-, 1984, pp. 139-140, fig. 85.

Thecocodium quadratum: Jarms, 1987, pp. 57-62, pp. 64-66, figs. 8.1-8.4. [change of genus]

Material examined: One medusa was collected by the author, using a polystyrene vessel. The animal was swimming just below the sea surface of the coast at Honmura $\left(33^{\circ} 27.0^{\prime} \mathrm{N}, 130^{\circ} 10.5^{\prime}\right.$ E), Kuchinoerabu Island, Kagoshima Prefecture, Japan on May 10, 1991. Within several hours

Publ. Seto Mar. Biol. Lab., 36(1/2), 89-92, 1993. (Article 6) 
after collection it was preserved in $7 \%$ formalin-seawater after being anesthetized using $\mathrm{MgCl}_{2}$ solution. Measurements were subsequently taken from the preserved medusa.

Description. The umbrella is $2.0 \mathrm{~mm}$ in height and $1.9 \mathrm{~mm}$ in diameter. The jelly is thickest at the umbrellar apex, measuring $0.7 \mathrm{~mm}$ in thickness. Four short tentacles are present, each inserted at the perradial exumbrellar furrows at the umbrellar margin. The base of each tentacle is covered by a collar-like structure, the core of which is red in color. A total of 127 nematocyst patches were present. Among them, 23 produced at the umbrellar margin are linear in shape, while the others are oval or round in shape and arranged meridionally in rows. In each quadrant, five or six linear spurs are present, and among them three or four spurs, which are longer than the other two or three spurs, are the most proximal ones in the row. There were 13 meridional rows of the nematocysts, each consisted of 2-14 oval clusters of nematocysts (mean $\pm \mathrm{SD}=8 \pm 3$ ) besides the linear one spur mentioned above. The manubrium, which is within the subumbrellar cavity, measured 0.5 $\mathrm{mm}$ in length. On the interradial portion of the manubrium, gonads are developing, being orange in color and tinted by red pigments. The sex is indeterminable. The oral lips are cruciform in shape and nematocysts are packed into perradial clusters.

Remarks. The present medusa has a greater number of linear spurs of nematocysts (23) at the umbrellar margin than those (20) found in the larger laboratory-reared medusa described by Jarms (1987). Furthermore, oval clusters of nematocysts extend more distally on the exumbrella of the present specimen, sometimes found close to
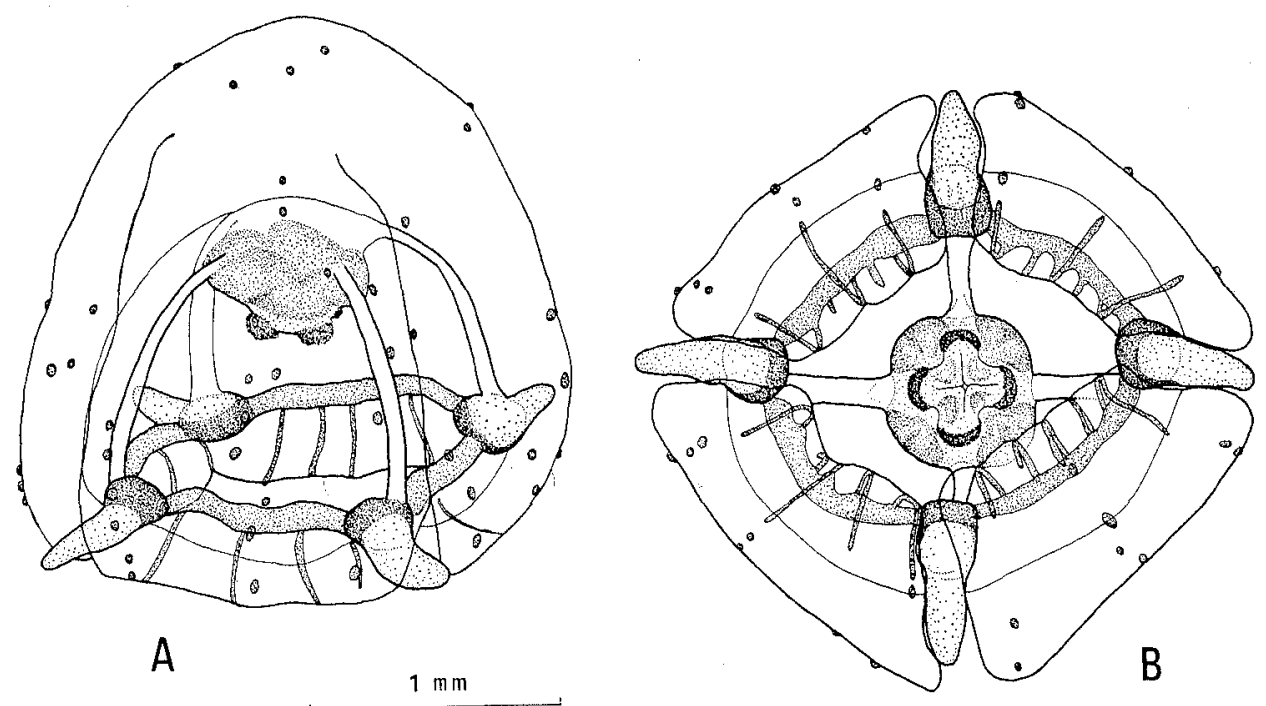

Fig. 1. Medusa of Thecocodium quadratum (Werner) from Kuchinoerabu Island, Japan, drawn from preserved specimen slightly contracted. A: Oblique view. B: Oral view of the same specimen (Note that three short spurs of nematocysts are not seen). 
the top of the umbrella. Moreover, the number of meridional rows of the nematocysts of the present medusa (13) is smaller than the holotype (may be at least 20) illustrated by Jarms (1987). Further, some specimens deposited in the Zoological Museum, University of Hamburg had additional interradial tentacles, up to four in number, besides the four perradial tentacles.

In Japanese waters, the present species is the fourth species recorded in the Ptilocodiidae. The other three known species are Ptilocodium repens Coward, 1909, Hydrichthella epigorgia Stechow, 1909, and H. doederleini Stechow, 1926 (Hirohito, H.M. the Showa Emperor, 1988; Yamada, 1959; Leloup, 1940; Stechow, 1909, 1913, 1926). Distribution. Only two widely separated localities are known for Thecocodium quadratum: Mombasa, Kenya as a hydroid record (Werner, 1965, 1984; Jarms, 1987) and Kuchinoerabu Island, southern Japan, as a medusan record (present study).

\section{Acknowledgements}

I offer my sincere thanks to Dr. Gerhard Jarms, University of Hamburg, not only for his valuable comments on the manuscript, but also his kind arrangement to send me the cultured specimens of Thecocodium quadratum deposited in the Zoological Museum, University of Hamburg (Cat. no. C 9297 and one bottle without number) for comparison with the present specimen. Many thanks are due to Dr. Claudia Mills, Friday Harbor Laboratories, for her kind improvement of the manuscript. I also wish to express my heartful thanks to Dr. Susumu Ohtsuka and the crew members of the Toyoshio Maru, Hiroshima University for their kind help in collection of the material.

\section{References}

Bouillon, J. 1967. Revision de la famille des Ptilocodiidae avec la description d'un nouveau genre et d'une nouvelle espéce. Bull. Acad. roy. Belg., Ser. 5, 53: 1106-1131.

- 1978. Sur un nouveau genre et une nouvelle espéce de Ptilocodiidae Hydrichthelloides reticulata et la super-famille des Hydractinoidea (Hydroida-Athecata). Steenstrupia 5(6): 53-67.

Brinckmann-Voss, A. 1970. Anthomedusae/Athecate (Hydrozoa, Cnidaria) of the Mediterranean. Part I. Capitata. Fauna Flora Golfo Napoli 39: 1-96, 11 pls.

Coward, W.E. 1909. On Ptilocodium repens, a new gymnoblastic hydroid epizoic on a pennatulid. Proc. K. ned. Akad. Wetensch., Sec. Sci. 11: 635-641.

Edwards, G. \& S.M. Harvey. 1983. Observations on the hydroids Coryne pintneri and Thecocodium brieni new to the British list. J. mar. biol. Ass. U.K. 63: 37-47.

Hirohito, His Majesty the Showa Emperor of Japan. 1988. The hydroids of Sagami Bay. Biol. Lab. Imp. Household, Tokyo, 179 pp. +110 pp. (text in Japanese), 2 maps.

Jarms, G. 1987. Thecocodium quadratum (Werner 1965) redescribed, T. penicillatum sp. nov., and a method for rearing hydrozoans. In Bouillon, J., Boero, F., Cicogna, F. and Cornelius, P.F.S. (eds.), Modern trends in systematics, ecology and evolution of hydroids and hydromedusae, Oxford University Press, London, pp. 57-66.

Leloup, E. 1940. Quelques hydropolypes de la Baie de Sagami, Japon, (2 note). Bull. Mus. roy. nat. Belg. 14, (28): 1-22, 1 pl.

Stechow, E. 1909. Hydroidpolypen der japanischen Ostküste. I. Abh. Bayer. Akad., Wiss. Math. -phys. Kl. Suppl. 1, (6): 1-111, pls. 1-7.

- 1913. Hydroidpolypen der japanischen Ostküste. II. Ibid. Suppl. 3, (2): 1-162. 96-108.

Werner, B. 1965. Lebensgeschichte und Ökologie tropischer Hydroid- und Scyphopolypen. Jber biol. Anst. Helgoland (1965). Ca 10-Ca 13. 
1984. Stamm Cnidaria, Nesseltiere. In Lehrbuch der speziellen Zoologie (coordinated by A. Kaestner). Band I Wirbellose Tiere (ed. H.-E. Gruner). 2. Teil: Cnidaria, Ctenophora, Mesozoa, Plathelminthes, Nemertini, Entoprocta, Nemathelminthes, Priapulida. 621 pp. Fischer, Stuttgart.

Yamada, M. 1959. Hydroid fauna of Japanese and its adjacent waters. Publ. Akkeshi Mar. Biol. Stat, 9: 1-101. 